\title{
Algumas considerações sobre educação em Jean-Paul Sartre
}

\author{
Walter Matias Lima
}

\begin{abstract}
Resumo
O artigo pretende identificar a relevância do tema: educação e razão dialética, em algumas obras de JeanPaul Sartre. Essa abordagem será permeada pela problematização das noções de razão dialética, práxis e antropologia, como as entende Sartre. Nossa intenção é mostrar a relação entre razão dialética e dialética da práxis e o contributo dessa relação para a prática educativa, a partir da concepção sartriana de antropologia. Partindo do aporte sartriano, compreendemos a educação como totalização que se traduz em projeto pedagógico que visa educar para a liberdade pela liberdade, desde que esta seja uma finalidade que se realize nas condições sócio-históricas e existenciais da práxis individual e coletiva. Assim sendo, a educação contém, como tessitura, a revolta, isto é, o poder (através do educador, do educando e das instituições) de protagonizar, sem quaisquer tipos de retraimentos e coerções, valores dos projetos pedagógicos e, entre estes, a efetivação da liberdade.
\end{abstract}

Palavras-chave: Sartre; Práxis; Educação; Dialética.

\section{Some commentaries on education in Jean-Paul Sartre}

\begin{abstract}
The article aims to identify the relevance of the issue: education and dialectical reason, in some works of JeanPaul Sartre. This approach will be permeated by questioning the notion of dialectical reason, practice and anthropology, as Sartre believes. Our intention is to show the relationship between dialectical reason and dialectics of praxis and the contribution of this relationship to educational practice, from the design sartriana of anthropology. On the intake sartriano we understand education as aggregation leading to pedagogical project aimed at educating for freedom for freedom, since it is a purpose to carry out socio-historical conditions and existential practice of individual and collective. Therefore, education contains as fabric, the revolt, that is, the power (through the teacher, the student and institutions) to play without any kind of withdrawal and constraints, values and educational projects, among these, the realization of freedom.
\end{abstract}

Keywords: Sartre; Praxis; Education; Dialectical. 


\section{Por que a revolta?}

Quando nos interrogamos sobre a revolta no mundo contemporâneo, na literatura e na filosofia contemporâneas, a experiência de Jean-Paul Sartre é indispensável. Portanto, nosso intento é apresentar algumas "linhas de fuga" do pensamento sartriano que, ao nosso ver, contribuem para pensar a relação entre educação, razão dialética e o tema capital da obra sartriana: a liberdade.

No nosso entender, a educação é a práxis que ajuda os homens a sair de sua inércia - da inércia da serialidade, levando os a totalizar eles próprios suas respectivas práxis em vez de sofrerem "a totalização reificada", "alienada" do prático inerte. Assim, desmistificar e reunir e não esquecer nossa presença concreta, nossa experiência psíquica, nem o momento concreto da história em que nos encontramos, mantendo um questionamento permanente, é o que põe uma atividade pedagógica como prática-revolta que se quer, também, desmistificadora e que se insere numa prática política que se recusa como espetacularização da vida e da morte, ensejando um processo dialético de superação das condições ideológicas e alienantes em que se encontram os sujeitos do processo educativo.

O lingüista Alain Ray, em seu livro Révolution, histoire d'un mot, traça o percurso etimológico e semântico da palavra "revolte": revolta ${ }^{1}$.

A primeira perspectiva está direcionada para a questão do movimento. $\mathrm{O}$ verbo latim volvere, está na origem de "revolte", termo que, no início, não se relaciona à política. Tendo as seguintes derivações: "courbe" (curva), "entourage" (ambiente), "tour" (circuito), "retour" (retorno).

No italiano, nos séculos XV e XVI, volutus, voluta sugerem a idéia de um movimento circular e, por extensão, de um retorno temporal. Ver, por exemplo, "retournement" (reviravolta).

Na acepção moderna da palavra, aparece o seguinte: "révolter" e "révolte", oriundas de palavras italia- nas; e, tendo preservado o sentido latino de "retornar" e "trocar", implicam um desvio que será assimilado a uma rejeição da autoridade. Assim sendo, no francês do século XVI, "révolter" é puro italianismo e significa "virar", "desvirar" (revoltar o rosto para o lado).

No século XVI, a palavra não comporta a noção de força, mas indica estritamente a oposição: no sentido de abjurar, desviar-se. Contudo, o sentido histórico e político da palavra se fixam no século XVII e no início do século XVIII: Voltaire, em $O$ século de Luis $X I V$, emprega "revolte" como "guerra civil", "perturbações" e "revolução".

$\mathrm{O}$ verbo latim revolvere aponta sentidos intelectuais: "consultar" ou "reler". "Révolution" passa em francês para o vocabulário científico, pois na Idade Média, "révolution" imprime o final de um tempo "révolu" (passado).

Portanto, a polivalência de sentidos, contidos no transcurso da palavra "révolte", mostra que o termo vai além do sentido político que tomou nos dias de hoje. A revolta, às vezes, desvia-se segundo a história. Nós é que temos que realizá-la.

Partiremos do seguinte pressuposto: uma prática educativa, que prime pela formação de uma práxis individual autônoma e livre, só existe ao preço de uma revolta, por uma educação-revolta e por um indivíduo historicamente situado e, sendo assim, por uma atividade educativa e pedagógica que busca a realização da liberdade como condição de humanização do homem. Nenhum de nós se satisfaz sem enfrentar um obstáculo, uma proibição, uma autoridade, uma lei que nos permita nos avaliar, autônomos e livres. A revolta que se revela, acompanhando a experiência íntima da aprendizagem é parte integrante do processo educativo. Precisamos de uma educação-revolta numa sociedade em que se vive, desenvolve-se e não estagna. Se essa cultura não existisse em nossa vida, seria o mesmo que deixar essa vida se transformar numa vida de morte, isto é, de violência física e simbólica, de barbárie. Há urgência em desenvolver essa perspectiva educativa a partir de nossa herança

1 Ver também o livro de Julia Kristeva: Sens et non-sens de la revolte. Paris: Arthéme Fayard, 1996, do qual tiramos as principais indicações sobre o tema da revolta em Sartre. 
cultural, ética e estética e encontrar para ela novas variações. Hoje, uma experiência da revolta, como instância educativa, pode nos livrar da robotização da humanidade que nos ameaça.

Nosso mundo moderno atingiu um ponto de seu desenvolvimento, em que certo tipo de educação, de cultura e de arte, se não toda a educação e toda a cultura, está ameaçada; muitas vezes, impossibilitada. Certamente, não a cultura-show, nem o que está se configurando nos moldes neoliberais como educação-show, ou a educação-informação consensuais favorecidas pelas mídias, mas justamente a educação-revolta ou a cultura-revolta. E quando essas se produzem, acontece que mostram formas tão insólitas e brutais que seu sentido parece perdido para aqueles que estão inseridos no processo educativo. Com isto, cabe a nós sermos os doadores de sentido, os intérpretes. Assim sendo, compreendemos a revolta como transgressão da proibição, como repetição, perlaboração e elaboração da experiência educativa e como deslocamento, combinações e jogos dos diversos sentidos que construímos através da atividade educativa e pedagógica.

Em relação a Jean-Paul Sartre, uma das marcas do tema da revolta está na sua constante perspectiva interpretadora, e entendemos a interpretação como um ato de revolta, de reconstruir significativamente uma experiência. Assim, podemos dizer que uma das características da revolta, para Sartre, é revelar a singularidade da experiência através da interpretação filosófica e literária, mostrando que a liberdade só existe ao preço de uma revolta. Que a práxis individual (na nossa perspectiva, quando atravessada pela atividade educativa) enseja a dinâmica da inteligibilidade da história, assim como a busca da liberdade.

Cremos que uma maneira de compreender o tema da revolta, em Sartre, é através de sua noção de liberdade situada, o que passamos a mostrar a seguir, apresentando uma perspectiva do transcurso dessa temática na obra do filósofo. Certamente, a experiência pessoal de Sartre se revela como uma situação, como uma luta por situar se dentro da situação com o fim de superá la. Esta experiência, contudo, não é tão pessoal, tão alheia ao comum dos mortais. Sartre viveu em sua experiência a intersubjetividade e o projeto fundamental que a define; auto-afirmação frente ao ser acabado, vontade de chegar a ser; compromisso com os empreendimentos concretos em nome do absoluto do projeto fundamental de determinar a existência a partir do futuro, em função de uma comum exigência de sentido e de considerar o passado apenas como o conjunto de condições sobre as quais devemos tomar apoio para intentar-nos a nós mesmos.

Em Sartre, esta referência ao absoluto de nosso projeto fundamental se resume como a aposta de Pascal: existe ou não Deus? Pascal apostou em sua existência, pois, no caso de existir, ganhava tudo e, no caso de não existir, nada perderia. Sartre, por sua vez, investiu a favor de seu absoluto, do absoluto do homem, à possibilidade da autodeterminação, a partir do futuro: ou a vida não é nada ou é tudo! Assim, segundo Sartre, consiste concretamente em decidirmos perder a vida antes de submetê-la ao absurdo. Esta aposta, contudo, apenas pode justificar-se mediante uma referência absoluta como ponto de apoio para ensejar-lhe sentido em cada uma das situações cotidianas. O incondicionamento de nossas tomadas de posição radica, segundo Sartre, em nos experimentarmos responsáveis por nossa superação em função de um futuro homem que devemos inventar: o que importa é a libertação do homem e, em função dessa libertação, sempre haverá algo que fazer.

$\mathrm{O}$ pensamento sartriano põe em jogo, desta maneira, uma dialética entre o otimismo da liberdade e o pessimismo de nossa contingência, entre a humildade que deve acompanhar o reconhecimento de nosso ser situado e o orgulho de nos reconhecermos agentes da história, entre a desesperança, à qual nos convida nossa situação, e a esperança que brota da situação, entre o impossível de nossas vãs ilusões e o possível de nossas pequenas ações. Dessa maneira, seu pensamento se revela como uma ética da práxis histórica que em seu dinamismo se orienta, não a um inerte universal já realizado, senão à universalização do ser humano situado.

A intencionalidade ética de Sartre se comprova no fato de que a primeira obra que ele anunciou, inicialmente, mas que nunca publicou, foi um tratado de 
moral. Apenas em 1975, deram-se a conhecer alguns fragmentos desta obra. É possível que sua não publicação se deva à necessidade que tinha Sartre de esclarecer previamente a correlação liberdade-situação implicada em sua visão do homem. O problema da práxis só podia ser enfrentado depois desse esclarecimento.

Liberdade, situação e práxis constituem, de acordo com o que foi dito antes, as categorias que expressam o problema sartriano. Elas estão em todas as suas obras, mesmo que não seja com o mesmo peso. Assim, até L'Être et le Néant (1943) o interesse de Sartre recai principalmente sobre o tema do homem como liberdade. A partir de então, até a Critique de la raison dialectique (1960), seu interesse se orienta até o tema da situação. Nos últimos anos, como síntese de sua trajetória, o tema da práxis ocupa o primeiro lugar.

A reflexão sobre o homem como liberdade se desenvolve em dois momentos. O primeiro é de ordem psicológica e esteve orientado a libertar o homem de todo EU (entendendo este como unidade indivisível) e de toda subjetividade entendida como sujeito transcendental: a partir de uma análise da consciência, Sartre radicaliza sua concepção de ser. O tema da situação está presente nestes primeiros momentos, mas em termos abstratos, a saber, como estrutura de todo homem enquanto homem. O ser-corpo, o ser-para-outro, o espaço e o tempo, entre outros, como características de toda liberdade em situação, são aspectos do ser do homem que Sartre não descuida. O tema central, contudo, é a liberdade como essência do homem: este não é o que é; é o que não é.

A reflexão direta sobre a situação permite a Sartre realizar análises concretas do homem enquanto comprometido dentro de uma determinada situação. $\mathrm{O}$ mundo aparece como suporte da liberdade, não o mundo como soma de coisas, mas o mundo como confluência de "situações concretas", isto é, o mundo transformado historicamente.

Finalmente, a práxis é abordada, desde uma crítica da razão dialética, crítica elaborada a partir de uma determinada concepção do marxismo que pretende recuperar a práxis individual como o ponto de partida real do pensamento de Marx. Contra o "mar- xismo dogmático", que tem absorvido o homem na idéia, Sartre pensa em um "marxismo existencialista" que busca o homem onde quer que se encontre, em seu trabalho, em sua casa, na rua. Isto lhe permite entregar-se a uma análise das condições reais de todo empreendimento humano, em termo de uma ética da história, para oferecer ao homem concreto, como agente da história, elementos para controlar a práxis em função de uma superação afetiva da contingência humana revelada em sua ontologia.

Como abordar o homem como liberdade situada? Sartre encontra elementos em Husserl e em Heidegger.

O que Sartre busca na fenomenologia? Sartre se refere a duas contribuições com relação direta com o sentido último de seu pensamento. Por uma parte, a intencionalidade, graças a qual lhe foi dado esvaziar a consciência de suas escorias, de seus estados, de descobrir o nada (a consciência) acossado incessantemente pelo ser, escapando sempre. Por outra parte, a ferramenta indispensável: descobrimos que nos encontramos situados.

Sartre reconhece sua dívida frente a Husserl das Idéias com sua ontologia da consciência pura; e para Heidegger, de Ser e Tempo, com sua analítica existencial da realidade humana. Em Esboço de uma teoria das emoções, nosso filósofo já havia escrito:

Existir para a realidade humana é, segundo Heidegger, eleger seu próprio ser em um modo existencial de compreensão: existir para a consciência é, segundo Husserl, aparecer-se. Porque mostrar-se aqui é absoluto, mostrar-se que é necessário descobrir e interrogar. Desde este ponto de vista, em cada atitude humana - por exemplo, na emoção, já que é nosso tema , Heidegger pensa que encontramos o todo da realidade humana, posto que a emoção é a realidade humana que elege e se dirige emocionada até o mundo.

Husserl por seu lado pensa que uma descrição fenomenológica da emoção trará a luz às estruturas essenciais da consciência, posto que uma emoção é uma consci- 
ência. E, reciprocamente, um problema se coloca, problema que o psicólogo não pode suspeitar: cabe conceber-se uma consciência que não restrinja a emoção entre suas possibilidades, ou melhor, pode nela verse uma estrutura indispensável da consciência? Assim o fenomenólogo interrogará sobre a consciência e sobre o homem e perguntará não apenas o que este seja senão se pode apreender um ser entre cujos caracteres haja um que seja precisamente a capacidade de emocionar-se. E, inversamente, interrogará a consciência, a realidade humana, com respeito a emoção: como deve ser a consciência para que a emoção seja possível e inclusive para que seja necessária? (SARTRE, 1995, p. 77-78).

Este texto sintetiza o que Sartre considerou de essencial em um e outro filósofo e a diferença entre os dois. Seu pensamento já tinha se formado definitivamente como para receber a influência posterior de Husserl do mundo da vida ou do Heidegger de Holzwege (caminho do bosque).

Interessado em uma ontologia da consciência em situação, Sartre radicalizou as oposições entre Husserl e Heidegger com o propósito de alcançar uma complementação na oposição. Desde este ponto de vista, também seguiu um caminho diferente ao de MerleauPonty. Este se interessou a harmonizar os dois filósofos em prol de uma síntese. Poder-se-ia dizer que Sartre toma de Husserl o método de investigação; e de Heidegger, a realidade humana como objeto desta investigação. Mas o faz de forma crítica.

Assim, Sartre considera que Husserl se limitou a descobrir o cogito em seu aspecto funcional, descartando o problema existencial para não cair no erro substancialista de Descartes. Ao não transcender a pura descrição da aparência enquanto tal, ficou preso ao cogito. Portanto, nas Idéias só podemos encontrar uma ontologia artificial da consciência pura desligada do mundo; por conseguinte, de uma consciência que não existe. Heidegger, por sua vez, ao querer evitar o fenomenalismo de Husserl, realizou, de forma direta, a análise da existência sem passar pelo cogito, privando assim, a realidade humana de sua dimensão de consciência ou concedendo-lhe uma simples "compreensão".

Fazendo dessa forma, Heidegger formula uma ontologia naturalista da existência pré-reflexiva. De acordo com esta crítica, Sartre assume de Husserl o método para descobrir a realidade humana enquanto consciência, centro de intenções e poder de iniciativa, contudo na medida em que o é dentro de sua mesma situação, pois do contrário, se alcançaria uma consciência que, ao apreender-se a si mesma em oposição ao mundo, seria o que não é (coisa). De Heidegger, nosso filósofo assume a visão da realidade humana situada no mundo, mas não como consciência que se quer apreender no mundo por fora de toda reflexão; ao contrário, à consciência só seria dado descobrir a impossibilidade de ser o que ela é (consciência).

Sendo assim, Sartre se esforçou por realizar uma complementação na oposição entre Husserl e Heidegger; uma ontologia que pensará a presença da consciência a si mesma como inseparável de uma autêntica presença do mundo; uma ontologia respeitará a correlação da consciência e da existência, da intencionalidade e de suas motivações, da liberdade que se afirma, quando a intencionalidade lhe confere sentido às motivações, mas que se nega quando as motivações se convertem em simples causas da intencionalidade.

Resumindo, o método sartriano para a análise do homem em situação pretende ser um método fenomenológico que, simultaneamente, permite opor, à tendência husserliana, a consideração da existência das essências, e à tendência heideggeriana, a consideração da essência da existência.

A aplicação desse método conduzirá Sartre a uma ambígua dualidade das essências: o ser em si da consciência e o ser em si das coisas, dualidade de termos que simultaneamente deixam em descoberto sua insuficiência: o "ser em si” em sua contingência se é suficiente a si mesmo, mas não pode justificar sua presença, sua possibilidade de "aparecer a" a consciência; o "ser para si", por sua vez, se é suficiente enquanto consciência para si teórica, mas não pode justificar sua própria existência. 


\section{Consciência e liberdade}

A reflexão de Sartre sobre o homem como liberdade se desenvolve em dois registros, como já vimos: o primeiro, registro psicológico, orientado a libertar o homem de todo "eu" e de toda subjetividade de tendência substancialista. $\mathrm{O}$ segundo registro, ontológico, orientado a esclarecer o sentido do ser, tanto do ser da consciência como do ser do mundo e a esclarecer a relação entre um e outro: "a primeira tarefa de uma filosofia deve ser... expulsar as coisas da consciência e restabelecer a verdadeira relação desta com o mundo, a saber, a de que a consciência é consciência posicional do mundo" (SARTRE, 1957, p. 18).

Os escritos sartrianos anteriores a L'Être et le Néant são dedicados à tarefa de expulsar todos os objetos da consciência e afirmar a falta de uma interioridade no homem: não haveremos de nos descobrir em algum retiro, senão no caminho, na cidade, em meio da multidão, entre as coisas, entre os homens. Desta época, interessam-nos as seguintes obras: La Transcendance de l'ego: esquisse d'une description phénoménologique (1936), Esquisse d'une théorie des émotions (1939) e L'Imaginaire (1940).

Sartre parte da idéia husserliana da intencionalidade: a consciência é, sempre, consciência de algo, ou seja, ela não existe mais que no mundo. Se isto é assim, é possível chegar à essência do homem a partir da análise fenomenológica de consciências ou condutas concretas. Toda conduta humana é conduta do homem no mundo. Por conseguinte, ela pode entregar, por sua vez, o homem, ao mundo e à relação que os une, à condição de que consideremos estas condutas como realidades objetivamente apreensíveis e não como afetações subjetivas que se descobririam apenas ante o olhar da reflexão. Sartre escolhe inicialmente duas condutas - emoção e imaginação - para esclarecer esta característica humana.

Nas Idéias, Husserl tinha ido mais além do sujeito empírico até um sujeito transcendental, com o fim de explicar a unificação e a individuação da consciência. Sartre, em La Transcendance de l'ego, sustenta a inutilidade deste recurso, pois, para ele, a unidade da consciência, mediante a qual se capta um objeto, pode ser explicada a partir da mesma intencionalidade.
A consciência unifica a si mesma e, concretamente, por um jogo de intencionalidades "transversais" que são retenções concretas e reais de consciências passadas. Em outros termos, é a consciência que é princípio de unidade para si, operando-se essa unificação no objetivo que a define, isto é, a intencionalidade aplicada a um objeto transcendente ou a uma vivência passada que por natureza a consciência capta como própria.

Na consciência, não se encontra, por conseguinte, nenhum sujeito: nem o psicológico que, de acordo com a redução, é um objeto transcendente para a consciência; nem o transcendental, que apenas é uma ficção operada a partir do sujeito psíquico. A consciência se define a partir de si mesma e não a partir de uma realidade ou uma substância: ela é existência pura; em si mesma, não é nada. Daí que ela não ofereça um âmbito interior que possa ser circunscrito mediante a inspeção e que dê lugar a algo que a defina como uma realidade distinta do mundo. A causa disso: o conhecimento não pode ser concebido como um processo de assimilação da exterioridade por uma interioridade: o mundo não entra na consciência. Pelo contrário, a consciência se define por sua presença ao mundo e por sua fuga de uma falsa interioridade comigo mesma: a consciência não tem um "dentro", não é senão o fora de si mesma, e essa fuga absoluta, essa negativa a ser substância, é o que lhe constitui como consciência.

Que significa, então, existir para uma consciência que em si mesma é nada? "Existir" para a consciência não tem o sentido corrente do termo, ou seja, pertencer à ordem da realidade em oposição à ordem das possibilidades puras. A consciência não é uma parte do mundo, é intenção até o mundo. O "existir" aponta aqui à espontaneidade, a partir da qual se constitui o mundo como objeto de todas as intenções e significações.

Enquanto espontaneidade, a consciência "determina a existência a cada instante, sem que possa conceber-se nada previamente a ela. Assim cada instante de nossa vida consciente nos revela uma criação $e x$ nihilo. Não um ordenamento novo, mas uma existência nova" (SARTRE, 1978a, p. 74). Esta espontaneidade equivale à liberdade pura, isto é, poder de 
auto determinação. A liberdade, por conseguinte, não é uma qualidade da consciência senão que é a existência anterior a toda determinação.

Esta liberdade, contudo, não se exerce fora do mundo, posto que o mundo é aquilo com respeito ao qual a consciência é criada. Sem ele não haveria consciência. A liberdade é, portanto, uma liberdade essencialmente situada. Mas por sua liberdade, a consciência foca, no mundo, possibilidades e sentidos que este não possui por si mesmo: a escolha livre da consciência sobre si mesma é, ao mesmo tempo, uma escolha sobre o mundo: "o possível, portanto, não pode vir ao mundo senão por um ser que é sua própria possibilidade" (SARTRE, 1957, p. 144).

Para explicar essa consciência livre, livre ante toda subjetividade e interioridade, Sartre descreve fenomenologicamente a emoção e o imaginar, transcendendo-os como simples fatos psíquicos, para que se manifestem como duas maneiras de existir, isto é, como duas possibilidades de eleger-se e compreender a consciência e, portanto, como duas formas de eleger e compreender o mundo.

A emoção, por exemplo, não é um acidente; e sim, um modo de existência da consciência, uma de suas maneiras de compreender seu ser no mundo. Apenas quando se estabelece esta significação, haverá lugar para as análises empíricas do psicólogo. Mediante a emoção, a consciência transforma irreflexivelmente um objeto ao não poder adaptar-se a ele: o mundo real é substituído por um mundo fictício, mágico, no qual desaparecem essas dificuldades. Desta maneira, a emoção é um jogo, mas um jogo no qual nós criamos. O desvanecimento, por exemplo, que um homem sofre ante um animal feroz é um "refúgio", uma evasão ante uma situação real, evasão que não consiste simplesmente em uma desordem fisiológica, mas em uma conduta que tem toda sua significação em uma intenção "negadora" da consciência: ante a impossibilidade de evitar o perigo pelas vias normais e os encadeamentos deterministas, nego esse perigo. Quero aniquilá-lo.

A urgência do perigo tem servido de motivo para uma intenção aniquiladora determinante de uma conduta mágica. Duas são as conclusões fundamentais às quais chega Sartre em sua análise da emoção. Em primeiro lugar, o mundo real, ainda que possua uma consistência, pode ser negado: a consciência pode assumir frente a ele uma distância que lhe permite viver no mundo elegido por ela mesma; mundo fictício, sem dúvida, mas que revela como a consciência é poder de negação do real. Em segundo lugar, as condutas da consciência são conscientes ainda que sejam reflexivas.

A análise da imaginação confirma esta liberdade que define a consciência: a imaginação é a consciência toda inteira enquanto que ela realiza sua liberdade. Os objetos imaginados nunca têm a consistência dos objetos reais. A consciência da cadeira em imagem me ensina que a consciência não é uma interioridade, onde se guardam, como simulacros, as imagens das coisas. Ela é um modo de ser da mesma cadeira que se dá na minha percepção. Se a consciência é intencional, imaginar não é possuir na consciência algumas imagens, mas uma maneira de espreitar o objeto, ou seja, sob a modalidade da ausência, modo, essencialmente, diferente ao da percepção para a qual o objeto se dá, segundo a modalidade da presença. Imaginar Pedro em Campinas, não é forjar uma realidade fantástica que substitua a presença de Pedro, mas ter consciência da ausência de Pedro: enquanto me aparece em imagem, este Pedro presente em Campinas me aparece como ausente.

$\mathrm{O}$ ato de imaginar revela que a consciência é ao mesmo tempo poder negador do mundo e consciência do mundo. Ela pode conceber outro mundo que é a negação do mundo real. Ao fazê-lo, põe de manifesto seu caráter livre: para que uma consciência possa imaginar, é necessário que ela escape do mundo por sua mesma natureza, é importante que ela possa tomar distância em relação com mundo. Em uma palavra, é essencial que ela seja livre. No entanto, encontramo-nos ante uma liberdade situada: eu só posso imaginar a partir da motivação concreta e precisa de uma situação que exclui o objeto mencionado de tudo que realmente me é acessível: porque Pedro não pode estar atualmente presente, eu o posso dar como ausente.

Uma imagem, dirá Sartre, não é o mundo-negado, pura e simplesmente, ela sempre é o mundo negado desde um determinado ponto de vista. 
Ao término das análises de sua psicologia fenomenológica, Sartre crê haver expulsado da consciência todo eu, toda interioridade, todo objeto. A consciência livre não é nada e, como nada, é liberdade. Desde um ponto de vista negativo, o poder da consciência livre se manifesta como poder de negação do mundo, da situação real dentro da qual se encontra o homem. Desde um ponto de vista positivo, a consciência pode regressar livre e criadoramente ao mundo, à situação para valorizá-la e dar-lhe sentido. Todo o anterior significa que ser livre, e ser em situação são a mesma coisa: a situação de um ser é sua existência superada e feita significante por sua liberdade; correlativamente, a liberdade de um não pode, por conseguinte, consistir em escapar a toda situação, senão na superação de sua existência bruta até uma situação.

Em L'Être et le Néant, Sartre sistematiza e esclarece os temas alcançados através da psicologia fenomenológica. A psicologia de tradição clássica quis explicar a realidade humana como uma coleção de dados observados, como um conjunto de qualidades hereditárias ou como uma substância sujeito de acidentes chamados fatos psíquicos. Sartre, com sua psicologia fenomenológica, buscou uma compreensão eidética da realidade humana, a partir da análise de condutas particulares enquanto fenômenos significantes da realidade humana em sua totalidade.

$\mathrm{O}$ aporte fundamental de $L^{\prime} \hat{E}$ tre et le Néant foi pôr de manifesto o ser da consciência, que a este ser corresponde um "dever ser": a consciência como existência livre corresponde a formulação de um projeto que lhe permite transcender o real, sem “aliená-lo, até um sentido e transcender o ato puro de negação, que a caracteriza, até o valor e a consistência deste ato".

Toda consciência é consciência de algo: "isto significa que a transcendência é estrutura constitutiva da consciência" (SARTRE, 1957, p. 28). Portanto, se quisermos descobrir a estrutura da consciência, temos que fazer referência às atitudes fundamentais do sujeito motivadas pelo mundo.

De acordo com isto, uma ontologia fenomenológica teria como objetivo esclarecer a ambigüidade do ser: do é de uma presença (a consciência) que não é um "em si” e do é de um “em si” (mundo) que só é definível a partir da consciência. Ela será a ontologia de uma consciência que, ao querer-se apreender como oposta ao mundo, deve fazer-se o que ela não é e que, na medida que se apreende sobre o mundo, mais além de toda reflexão, descobre a impossibilidade de ser o que ela é.

A necessidade desta ontologia se impõe, caso tenhamos em conta que o mundo, como correlato da consciência, o é de tal forma, que a consciência facilmente se esquece de si mesma em benefício de um mundo objetivado e converte suas valorizações em simples constatações e sua presença, em um simples olhar os objetos como determinados em si mesmos e possuidores por si mesmos de um sentido que só lhes pode ser outorgado pela consciência.

$\mathrm{O}$ ser em si. A consciência é consciência de algo que lhe é transcendente. Por conseguinte, não tem sentido a pergunta sobre como o ser do objeto se distingue do ser da consciência: "ser consciência de algo é estar ante uma presença concreta e plena que não é a consciência" (SARTRE, 1957, p. 27).

Contudo, o ser não se entrega inteiramente em cada uma de suas manifestações: ele se anuncia no fenômeno em forma transfenomenal como um mais além do fenômeno. Daí que todo fenômeno, que por definição é um "ser para a consciência", seja ao mesmo tempo um "ser em si”. Ele é para a consciência só enquanto não é consciência, enquanto é aquilo que a consciência não é. Por conseguinte, quando se fala do "ser em si", se quer afirmar que o ser que se dá à consciência como fenômeno, se dá como possuindo em si mesmo seu sentido de ser e seu fundamento. $\mathrm{O}$ ser se cria então a si mesmo? Não podemos afirmar, pois isto implicaria a utilização de categorias que só se aplicam ao homem, isto é, as categorias de atividade e passividade. Do ser só se pode dizer que "é em si”, ou seja, que é idêntico a si mesmo e pleno de si como o ser de Parmênides: ele é simplesmente, sem necessidade de nenhuma razão: "Isto é o que a consciência expressará - em termos antropológicos - dizendo que o ser está de mais, ou seja, que ela não pode de modo algum derivá-lo de nada nem de outro ser, nem de um possível, nem de uma lei necessária. Não criado, sem razão de ser, sem relação alguma com outro ser, o "em si" está eternamente de mais" (SARTRE, 1957, p. 34). 
Para Sartre, a consciência não pode explicar este ser "em si”. Na esteira heideggeriana, considera que a consciência compreende de forma imediata sua situação sem necessidade de uma explicação: o fenômeno de ser, como todo fenômeno primeiro, se desvela imediatamente à consciência, através de meios "de acesso imediato (como) o tédio, a náusea, etc." (SARTRE, 1957, p. 14). Recordemos Roquetin em La Nausée, quando descobre o sentido concreto da palavra "existência": "de um só golpe a existência se faz presente a ele, não a existência de um determinado objeto que eu posso nomear, utilizar ou definir, mas a existência de algo absoluto, a contingência [...] Existir é está aí simplesmente; os existentes aparecem, se deixam encontrar, mas nunca é possível deduzilos. Tudo o que existe nasce sem razão, se prolonga por debilidade e morre por causalidade".

O ser para si. O "ser em si", de acordo com o que foi posto até o momento, não dá margem a nenhuma pergunta. Se alguma pergunta tem surgido, é porque uma alteridade, que é um não ser, introduz-se no coração do ser. Trata-se da consciência. Se a consciência é algo distinto do objeto do que ela é consciência, ela não é nada mais que consciência desse objeto, até o ponto de que a existência do objeto significaria a não existência da consciência. Algo mais: se a consciência é consciência de algo - deste monitor, por exemplo - este algo é arrancado da massa de ser e constituído como não sendo nada mais do que o que é.

Assim sendo, se segue que esse algo é um ser com respeito a esse algo. Dessa maneira, a consciência é triplamente fonte de não ser: com respeito a si mesma, enquanto ela não é nada do objeto e enquanto ela não é nada sem ele; com respeito ao objeto, enquanto a causa dela, este não é nada mais que o que é, tal como o expressamos nos juízos de negação; e, com respeito ao mundo enquanto este, como totalidade estruturalmente diferenciada, só se dá pelo nada.

Se quisermos saber como o ser pode estar afetado pelo nada, teremos que buscar uma explicação pelo lado de uma dimensão do ser que seja portadora de sua própria negação, já que o "ser em si” não dá lugar a nenhuma diferenciação ao ser idêntico a si mesmo. Este ser, que só é graças a "ser o que não é”, é a consciência livre e espontânea. Enquanto tal,
Sartre a denomina "o ser para si”, porque é livre e, por conseguinte, porque propõe "a ser", ela não apenas "e o que não é" com respeito ao "ser em si", como também com respeito a si mesma.

A unidade do em si e do para si. Como poderíamos pensar unilateralmente estas duas regiões do ser? "Se o "em si" e o "para si” são modalidades do ser, não haveria um hiato no senso mesmo da idéia do ser, e não estaria cindida sua compreensão em duas partes incomunicáveis" (SARTRE, 1957, p. 715). A possibilidade de um pensar unitário apenas se pode dar, desde um ponto de vista do "para si", posto que, como foi dito, o "em si” não é suscetível de nenhum ponto de vista.

No olhar do fenomenólogo, o "em si" e o "para si" aparecem, de fato, como correlativos: não temos intuição de um "para si” separado e que por isso mesmo seja um puro nada, nem de um "ser em si" puro. Quem se expresse nesses termos, estará se expressando em termos abstratos.

Quando a consciência estabelece "o em si”, o faz como anterior ao "para si” e anterior às perguntas que ela possa colocar-se, perguntas que, por certo, não a afetam no "em si", não dão margem à busca de uma origem do ser: "o ser é sem razão, sem causa, sem necessidade" e "todos os 'por quês'... são posteriores ao ser e os supõe" (SARTRE, 1957, p. 713).

A consciência pode, contudo, interrogar-se sobre a origem de seu próprio ser: "o ser pelo qual o porquê chega ao ser tem o direito de colocar seu próprio porquê, posto que ele próprio é uma interrogação, um porquê. A esta questão a ontologia não poderia responder, pois se trata aqui de explicar um acontecimento e não de descrever as estruturas de um ser" (SARTRE, 1957, p. 714). Deve-se alertar, contudo, que a resposta dada constitui uma hipótese metafísica que afirma a aparição acidental, absurda contingente da consciência como um nada que só através de suas escolhas conquista uma essência, essência que surge dessas escolhas livres enquanto ultrapassadas pela consciência: a essência da consciência é sua existência petrificada. Devese sublinhar, portanto, que a consciência, ao não obedecer a nenhum condicionamento externo, pode refazer continuamente sua essência. Neste sentido, a existência precede a essência. 
A consciência, enquanto pergunta, é levada a inquietar-se sobre a possibilidade de um "ser total", isto é, de uma síntese unitária do "em si” e do "para si”. É possível esta síntese? Não, posto que se trata de termos que se excluem: o "ser em si" não pode converter-se em consciência nem a consciência em um "ser em si”, pois deixariam de ser o que são. À medida que o homem aceite este projeto impossível, ele é uma "paixão inútil", um esforço falido de antemão.

A liberdade. "Que deve ser o homem em seu ser para que, através dele, o nada chegue a ser?" (SARTRE, 1957, p. 60). A interrogação sobre uma essência do homem parece contradizer a afirmação de que a consciência é apenas existência. A contradição é aparente se tivermos em conta o que se deve entender por essência.

A liberdade não é uma propriedade qualquer de meu ser: ela é "a textura de meu ser" (SARTRE, 1957, p. 514). "O que chamamos liberdade não... se distingue do ser da 'realidade humana'. O homem não é primeiro, para ser livre depois, não há diferença entre o ser do homem e seu 'ser livre"' (SARTRE, 1957, p. 61). A liberdade é o poder da consciência de negar o ser e negar-se a si mesma e, ao fazê-lo, afirma-se a si mesma, de determinar-se, de eleger-se, de criar-se perpetuamente. Do homem livre, só se pode captar o que tem sido, não o que é e o que será: “a liberdade é o ser humano colocando seu passado fora de jogo e segregando seu próprio nada" (SARTRE, 1957, p. 65). Este "por fora de jogo" meu passado, radica a possibilidade de contemplar meu ser passado como se já não fosse meu ser e, portanto, a possibilidade de introduzir a descontinuidade.

Dessa forma, o homem não é pura existência, o que significaria ser um existente imaterial. Ele é uma essência problemática, porque está sempre por fazerse a partir de sua liberdade: "a liberdade humana precede a essência do homem e a torna possível; a essência do ser humano se faz em suspenso em sua liberdade" (SARTRE, 1957, p. 61). Aparece, precisamente, a angústia, esse sentido que acompanha o homem atuando sobre a situação, escolhendo-se e escolhendo livremente seu mundo, sem leis nem critérios absolutos que possa constrangê-lo em um sentido ou em outro e que, por outra parte, lhe assegura o êxito de seu projeto. A única lei que lhe orienta é sua liberdade: "estou condenado a ser livre. Isto significa que não se pode encontrar mais limites para minha liberdade que esta mesma, ou, se preferirmos, que não somos livres para deixar de ser livres" (SARTRE, 1957, p. 515).

A angústia se revela, assim, como a apreensão do caráter inelutável da liberdade que deve decidir por si mesma o dever ser do homem:

Estou emergindo sozinho, e, na angústia frente ao projeto único e inicial que constitui meu ser, todas as barreiras, todos os parapeitos desabam, nadificados pela consciência de minha liberdade: não tenho nem posso ter qualquer valor a recorrer contra o fato de que sou eu quem mantém os valores no ser; nada pode me proteger de mim mesmo; separado do mundo e de minha essência por esse nada que sou, tenho de realizar o sentido do mundo e de minha essência: eu decido, sozinho, injustificável e sem desculpas"(SARTRE, 1957, p. 77).

Assim sendo, Sartre vai insistir no caráter prático da filosofia: "Toda filosofia é prática, inclusive aquela que à primeira vista parece ser a mais contemplativa" (SARTRE, 1960, p. 16). O reconhecimento deste caráter prático da filosofia aproxima Sartre ao pensamento de Marx.

Conceber a consciência como um elemento da natureza, ou tomar literalmente que "o ser determina a consciência”, é não apenas negar a liberdade da consciência, como também cair no idealismo que se quer rechaçar, pois é apontar à natureza uma teleologia: "é certo que o ser determina a consciência, mas se tinha, em certa maneira, 'o projeto' de determiná-la, então voltaríamos à idéia hegeliana”. O que faz do pensamento de Marx "a filosofia de nosso tempo" não é esse parco materialismo, mas o "ser a tentativa mais radical de esclarecimento do processo histórico na sua totalidade" (SARTRE, 1960, p. 29) respeitando, simultaneamente, a especificidade da existência humana e o caráter concreto do homem em sua realidade objetiva. 
Podendo, por tudo isso, em que o existencialismo poderia influir no marxismo? Para Sartre, o marxismo se tem detido ao fazer de seus princípios dogmas, convertendo-se em um idealismo voluntarista. O existencialismo pode acrescentar ao marxismo uma base para pô-lo em marcha, a saber, sua concepção de práxis individual, graças à qual a vida não é um fenômeno estático, mas dinâmico.

Para compreender o homem, nós temos que situálo, prontamente, no seio da totalidade, mas também temos que pô-lo em relação com o devir concreto: "para mim, escreve Sartre, a verdade devem, é e será no devir. É uma totalidade que se totaliza sem cessar; os fatos particulares não são nem verdadeiros nem falsos, embora não são relacionados pela mediação das diferentes totalidades parciais com a totalização em curso" (SARTRE, 1960, p. 30).

Para abordar a história, como verdade que está em devir, temos que utilizar a razão dialética. Utilizar a razão analítica - válida no conhecimento do mundo natural - seria aceitar de antemão um determinismo que anularia a consciência como projeto e liberdade.

Sartre se opõe, contudo, à interpretação da dialética por parte do marxismo francês e soviético porque, precisamente, esta interpretação assume que o devir histórico e o devir do universo poderia ser explicado a partir de leis universais, expressões de uma dialética existente na natureza. Para Sartre, não é a natureza a que procede dialeticamente como negação, negação da negação e subsunção desta numa negação mais rica. Apenas a consciência pode introduzir, através da práxis intencional, a negação no universo do ser-em-si.

Quais são os limites da razão analítica? A formulação das leis de tudo o é e chega a ser no mundo natural, mediante a observação, a experimentação, a redução do complexo a seus elementos simples, à dedução e à síntese. Este conhecimento permite ao pesquisador esclarecer os fatos novos, reduzindo-os ao passado. O pesquisador pode, por conseguinte, sentir-se orgulhoso de sua capacidade de predição. Mas a razão analítica nada pode dizer-nos acerca dos fenômenos sociais que são produtos de uma práxis que, a cada instante, cria o novo que rechaça toda instauração de cadeias causais para sua explicação.
A razão dialética pode encontrar "a partir das estruturas sincrônicas e de suas contradições, a inteligibilidade dinâmica das transformações históricas, a ordem de seus condicionamentos. A razão inteligível da irreversibilidade da história, isto é, sua orientação" (SARTRE, 1960, p. 156). As mudanças históricas, enquanto provenientes de uma consciência livre, são imprevisíveis. Se elas são compreensíveis, o são porque são intencionais e porque podem ser integradas no fenômeno humano em seu conjunto: a práxis humana remete à totalidade da humanidade.

Nesse sentido, Sartre não desenvolve o método dialético. Sua dialética é mais uma teoria do conhecimento, uma lógica que pretende explicar de maneira não contraditória os momentos da totalização, lógica da ação criadora, lógica da liberdade. Para Sartre, o homem, mediante a práxis, deve satisfazer suas necessidades num mundo de "escassez". Daí que esta implica privar o outro necessariamente de algo, originando assim um antagonismo violento. Apesar disto, o homem pode interiorizar as situações e reexteriorizá-las através de uma práxis orientada ao reconhecimento e à libertação do Outro. É este caráter teleológico da práxis o que, finalmente, distingue o homem do animal, tornando o homem histórico e ético.

A Crítica da Razão Dialética também se coloca como problema estabelecer ou "deduzir" as condições de possibilidade da história. Sartre diz que a realidade da história, em sua generalidade, já está assegurada pelo próprio estatuto da práxis, a qual, desde a emergência orgânica, constitui-se como capacidade de superação e de totalização. Portanto, o que deve ser fundado é nossa história, caracterizada pela exploração e pela violência. O materialismo sartriano é rigoroso: é preciso que a possibilidade do devir dramático da humanidade se instaure na relação prática primordial. Portanto, ele admite como um dado o fato da escassez. Fornecendo previamente um conteúdo "econômico" à "guerra de todos contra todos", designada por Hobbes como estado natural, Sartre irá compreender doravante toda história como algo que se explica sobre o pano de fundo dessa carência radical. É nesse sentido que é interpretada a fórmula marxista, segundo a qual os homens viveram até aqui 
sua pré-história, pois a história só terá início quando eles tiverem vencido a adversidade natural.

É a partir da perspectiva abordada acima, que entendemos a práxis educativa como a realização de uma educação-revolta e efetivação de uma abordagem antropológica que põe em evidência a busca da liberdade e a constituição da inteligibilidade da história.

Assim, insistir em uma abordagem que enfatize a dimensão antropológica da atividade educativa possibilita descobrir que a práxis individual, no seu esforço incessante para se objetivar, para cumprir o projeto de ser, apreende-se como inteligível e histórica em si mesma. Subjacente a esta práxis individual de ser, há sempre uma escolha que a define precisamente pelo seu fim, sem prejuízo de assumir um passado que traça a situação que a envolve e a constrange no limiar da historicidade, uma vez que o sujeito descobre que não está sozinho. $\mathrm{O}$ projeto ${ }^{2}$ e a decisão que o sustém identificam a liberdade do homem enquanto exprimem a sua atitude (revolta), a sua perspectiva, diante de uma situação que, inevitavelmente, o ultrapassa.

Como podemos depreender, aparece aqui a problemática da liberdade humana na sua dimensão subjetiva e na sua relação com a necessidade objetiva das determinações históricas. Eis que ambas as situações se resolvem não tanto pela imposição de um ou outro dos pólos da questão em jogo, mas precisamente pela afirmação da atividade educativa do homem, a ser exercida na prática, mas sempre assente no conhecimento da verdade em toda a sua objetividade. É, aliás, assim que o homem é levado a olhar o futuro e a querer acelerar a sua ocorrência pela representação que dele pode fazer por antecipação. A educação tem, dessa maneira, por significação e por tarefa, participar na realização dos fins da história e abrir a via às mudanças que devem necessariamente intervir na compreensão dos homens, de maneira a fazêlas realizar.

Portanto, a educação detém um papel decisivo no desenvolvimento conjunto da civilização e da existência humana; enquanto o projeto social de ambas ultrapassa necessária e concorrentemente o presente, desafiando-o, ou seja, inculcando nele a sua presença superadora. Tal presença será tanto mais ativa quanto mais consciente, isto é, quanto mais despertos pela práxis educativa - estiverem os indivíduos para essa realidade evolutiva que, de uma só vez, os ultrapassa, os atinge e os solicita, apelando à sua participação num projeto que, sendo coletivo (muito embora possa ser concentrado no sujeito singular), implica a adesão pessoal. Favorece ao mesmo tempo e, dessa forma, a realização histórica das sociedades e de cada homem tomado como um indivíduo nelas integrado.

E é dessa maneira que entendemos a noção de educação-revolta: uma prática educativa e pedagógica que leva o indivíduo a ultrapassar, negar ou modificar os limites da sua própria condição, a saber: a necessidade de estar no mundo, de aí estar com os outros e de ser mortal. Estes limites, se são objetivos, porque condicionam todos os indivíduos; são igualmente subjetivos, porque são vividos por cada um e nada são se o homem os não viver. Nessas circunstâncias, todo o projeto existencial e educacional, sem prejuízo de ser individual, desfruta de um valor universal.

2 Projeto entendido também como atividade educativa e pedagógica e, portanto, como projeto antropológico. 


\section{Referências}

HUSSERL, Edmund. A Idéia da Fenomenologia. Lisboa: Edições 70, 1985.

HUSSERL, E. Idées directrices pour une phenoménologie et une philosophie phénoménologique pures. Livre I, Introduction générale à la phénoménologie pure. Trad. P. Ricouer. Paris : Galimmard, 1950, Bibliothèque de philosophie.

HUSSERL, E. Méditations cartésiennes. Introduction à la phenoménologie. Trad. G. Peiffer et E. Levinas. Paris : Vrin, 1980

KRISTEVA, Julia. Sens et non-sens de la révolte. Paris : Arthème Fayard, 1996.

SARTRE, Jean-Paul. Critique de la raison dialectique: Théorie des ensembles pratiques. Tome I (précédé de Questions de méthode). Paris: Gallimard, 1960. (reeditada em 1985)

Critique de la raison dialectique: Lïntelligibillité de l'Histoire. Tome II. Paris: Gallimard, 1985. (Établissement du texte, notes et glossaire par Arlette Elkaïm-Sartre).

Huis Clos, suivi de Les Mouches. Paris:

Gallimard, 1947.

Le Diable et le bon Dieu. Paris: Gallimard, 1951.

L'être et le néant. Essai d'ontologie phénoménologique. Paris: Gallimard, 1957.
El escritor y su lenguaje. Situación nueve y otros textos. Tradução de Eduardo Gudiño Kieffer. Buenos Aires: Losada, 1973.

. On a raison de se révolter. Paris : Gallimard, 1974.

La Transcendance de l'ego : esquisse d'une description phenoménologique. Intrudução, notas e apêndices por Sylvie Le bon. Paris : Vrin, 1978a.

Reflexões sobre o racismo. Tradução de J. Guinsburg. Rio de Janeiro: Difel, 1978b.

Questão de Método. Tradução de Bento Prado Junior. São Paulo: Abril Cultural, 1978c.

. O Existencialismo é um Humanismo. São Paulo: Abril Cultural, 1978d. (Coleção ‘Os Pensadores’'). .Cahiers pour une morale. Paris: Gallimard, 1983. Escritos Políticos: 1. Política Francesa. Madrid: Alianza, 1986.

. A Náusea. Tradução. Rita Braga. 6ª ed., Rio de Janeiro: Nova Fronteira, 1986.

Situations Phiplosophiques. Paris: Gallimard, 1990.

.Em defesa dos intelectuais. São Paulo:Ática: 1994.

Esquisse d'une théorie des émotions. Paris: Hermann, 1995.

\section{Sobre o autor:}

Walter Matias Lima é Doutor em Educação pela UNICAMP, professor do Centro de Ciências Humanas, Comunicações e Artes da Universidade Federal de Alagoas. Professor Adjunto do Curso de Licenciatura em Filosofia e dos Mestrados de Sociologia e de Nutrição, da mesma universidade. Coordena o Núcleo de Estudos e Pesquisa em Ética e Ensino de Filosofia. 
